\title{
A review of highly superior autobiographical memory
}

\section{Son derece üstün otobiyografik bellek hakkında bir derleme}

Filiz Sayar

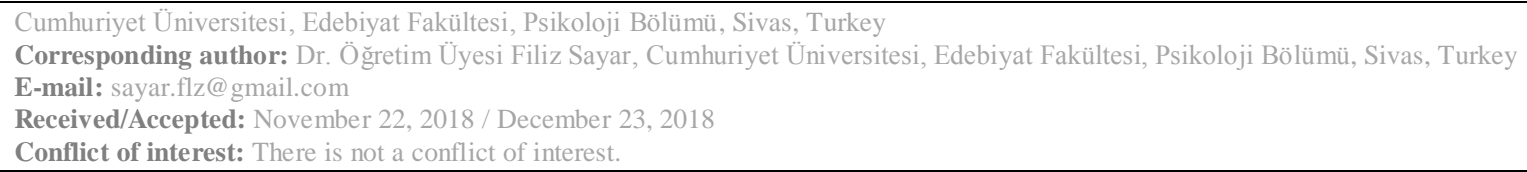

In this article, highly superior autobiographical memory (HSAM) was examined as a prominent ability that taking attention in recent years and providing crucial information about functioning of autobiographical memory and it was aimed to make a general review based on results of studies. HSAM refers to automatically, uncontrollably and extraordinarily remembering of personal and public experiences, information, dates without any use of memory strategies. HSAM is also known as hyperthymestic syndrome from the word thymesis in Greek which means remembering. HSAM individuals remember personal and public events extremely detailed than those in the control group while they show similar performance to them in other memory tasks (such as, digit span, word-paired memory). HSAM cases are considered to be different from other superior memory cases because they do not use any mnemonic techniques and do not have savant syndrome characteristics. In the results of behavioral and neuroanatomical studies it was postulated that HSAM and OCD could a common underlying mechanism but no definitive conclusion could be reached on this issue. It is believed that future research will remove many question marks on HSAM.

Keywords: autobiographical memory, highly superior autobiographical memory, memory functions

\section{ÖZET}

Bu makalede, son yıllarda dikkati çeken ve otobiyografik belleğin işleyişi hakkında önemli bilgiler edinmemizi sağlayan bir yetenek olarak son derece üstün otobiyografik bellek (highly superior autobiographical memory) ele alınmış, elde edilen araştırma sonuçlarına dayanılarak bu konu hakkında genel bir derleme yapılması amaçlanmıştır. Son derece üstün otobiyografik bellek (SDÜOB), kişisel yaşantıları, bilgileri, yaşanılan olayların tarihlerini ve ayrıntılarını herhangi bir bellek stratejisi kullanmadan otomatik, kontrolsüz ve olağanüstü bir şekilde hatırlama yetisine işaret etmektedir. SDÜOB hatırlamak anlamına gelen Yunanca thymesis kelimesinden gelen hyperthymestic sendrom olarak da bilinmektedir. Bu konuda yapılan çalışma sonuçlarına göre, SDÜOB vakaları kişisel ve toplumsal olayları kontrol grubundaki katılımcılardan son derece ayrıntılı hatırlarken diğer bellek testlerinde ise onlara benzer bir performans gösterdikleri gözlenmektedir. Bu vakalar herhangi bir bellek geliştirme tekniği kullanmadıkları ya da savant özellikler göstermedikleri için üstün belleğe sahip diğer vakalardan farklı olarak değerlendirilmektedirler. Elde edilen davranışsal ve nörogörüntüleme araştırma sonuçlarına dayanarak son derece üstün otobiyografik bellek ile obsesif kompülsif bozukluk arasında ortak altyapısal bir mekanizmanın olabileceği olasılığı üzerinde durulmuş fakat bu konuda net bir sonuca varılamamıştır. Gelecekte yapılacak çalışmalar HSAM hakkındaki birçok soru işaretini ortadan kaldiracaktır.

Anahtar sözcükler: otobiyografik bellek, son derece üstün otobiyografik bellek, bellek işlevleri 


\section{INTRODUCTION}

As a cognitive ability that it has been tried to unravel its mystery in the recent years, highly superior autobiographical memory (HSAM) is used for cases that people can remember any details about their past personal experiences accurately and vividly without using any mnemonics ${ }^{1,2,3,4}$. One of the most important characteristics of HSAM individuals is that they extremely perfect remember information about their personal lives and the public events that concern them, and do not use any mnemonic techniques in doing so and they are distinguishable from other cases of superior memory not to use other strategies such as repetition of autobiographical events that they lived. Another feature is that they perform similar to those in the control group in other memory tasks that are applied in the laboratory even though they have extraordinary autobiographical memories. On the other hand, in a false memory study it was observed that they have extraordinary autobiographical memory, but they are not immune to false memory distortions ${ }^{4}$. They recalled wrongly a nonexistent event (footage of a plane crash) as likely as controls when they are given misinformation. These results are important to show that having extraordinary autobiographical memor does not mean no false recollection and that HSAM participants and controls use the same reconstructive mechanisms while remembering autobiographical information.

In this context, the aim of this article is to give various information and to provide general points of view about HSAM based on results of studies. The HSAM, also known as hyperthymestic syndrome, was first introduced in 2006 by a case by Parker et al. ${ }^{5}$. According to the case called as $\mathrm{AJ}$, she was able to recall details about her personal experiences to the perfect degree without using any mnemonics. That is, she recalls autobiographical information about herself automatically, uncontrollably, not using any cognitive strategy. A case similar to AJ, described as before AJ, was Henkle's case in 1871 Daniel McCartney (DM) who could recall the details of certain events extremely well from mid-childhood onwards more than early childhood, like AJ ${ }^{6}$.

As a result of the neuropsychological assessment on AJ, she could remember correctly what she was doing at any given date from the age of 14 to the present. To provide control over reliability of her answers, the questions and dates were asked in a way that she could not make any preparation. It also was observed that $\mathrm{AJ}$ remembered the social events of the past very well if she was interested in the incident. Her cognitive functions were investigated by the detailed questions about her personal history, examination of diaries as well as application of many other neuropsychological tests (general memory, attention and working memory, face perception, olfactory functions, executive functions and reasoning, anterior left hemisphere tests, organizationally -demanding memory tests, face memory test). The extraordinary results obtained from autobiographical memory as a result of the all neuropsychological evaluations could not obtained from other standard cognitive tests. It was observed that as if she had a mental calendar and she remembered the personal and public events of any given dates nearly perfect.

In interviews with $\mathrm{AJ}$, she mentioned how she felt as if she were in prison of her memories due to persistently recall of her past memories. She finds her remembering sometimes soothing sometimes burdensome. Memories like an ongoing film in her mind are stimulated by all-time retrieval clues, and $\mathrm{AJ}$ says that it is impossible to prevent this. In other words, it could be assumed that the mind of the $\mathrm{AJ}$ is buried in the past. A memory activates other memories in an uncontrollable way by automatically stimulating another memory. AJ was unable to inhibit her memories not to remember, and she spent a lot of time thinking about them. Although many people, like AJ, have many memories to be stimulated by certain retriveal cues, it is unlikely that we know specifically what we do at a certain date. In this context, these results show difference of $\mathrm{AJ}$ 's autobiographical memory from other people's autobiographical memory. On the other hand, it was also observed that this extraordinary remembering of autobiographical memories is not valid every past experience and has a selective characteristic. Conversely, it also indicates that superior autobiographical memory of AJ compels her by spending too much time thinking about the past, rather than making his work easier in life.

Parker et al., as a result of their observations concluded that the hyperthymestic syndromes of AJ is based on her incompetent management of executive functions ${ }^{5}$. Accordingly, because AJ was unable to inhibit automatic retrieval of her memories, her ability of autobiographical memory improved by remembering her memories over and over. As a result of neuropsychological evaluations, frontostriatal disorder was detected in $\mathrm{AJ}$ and some deficits were detected especially in executive functions. In addition, atypical frontal lobe functions, obsessive-compulsive tendencies 
and anomalous lateralization were also found. As known, neurodevelopmental frontostriatal disorders include autism, ADHD and obsessive compulsive disorder (OCD) and in this context it was assumed that although AJ does not have autistic savant characteristics, she may have specific and obsessive information processing by showing similar features to savants.

LePort et al., in their study with 30 HSAM individuals (19-68 years old) and 20 controls, they asked participants to explain in detail the events that happened 1 week, 1 month, 1 year and 10 years ago ${ }^{7}$. As a result, although HSAM participants and controls provided the same number of information, forgetting in HSAM individuals were found to be much slower and their remembering of routine events even more highly than controls. It was observed that HSAM individuals compared to controls they had richly detailed recollection as if they re-experience them. Also, the results indicated that they were not better to encode the information but superior at retaining information. When checked accuracy of recalled information it was found to be completely accurate. When time limit (2-min time limit) was applied, HSAM subjects told more detailed memories and when controls was re-tested 1 month later, controls explained their memories more generally, while HSAM participants recalled episodic like details.

In a study comparing HSAM individuals with controls in terms of cognitive assessment the results indicated that although HSAM participants were superior in remembering their autobiographical events, they were better in only a few cognitive tests compared to controls ${ }^{1}$. While HSAM participants were more successful than controls in California Verbal Learning Task, Face-Name-Occupation, Script Generation, Three Phase Story and The Meta-Test, any significant difference was not found in tasks such as Mental Imagery, Stroop Task, Mnemonic Similarity Task. Although differences were obtained on few tasks but the size of effects was smaller when the nature of tasks does not have autobiographical characteristics in HSAM participants.

As a result of the neuroimaging investigations, nine brain regions different from the controls were identified in the HSAM participant ${ }^{2}$. According to whole-brain structural MRI scans some structural differences were detected in the inferior and middle temporal gyri, temporal pole, and the anterior insula and the parahippocampal gyrus regions of the HSAM participants. In this context, many studies indicated that these brain regions are responsible for the functions of autobiographical memory ${ }^{8}, 9,10,11,12$. These results show that differences in the medial temporal region of the left medial and bilateral middle temporal gyri may explain the rich detailed personal and public memory of the HSAM participants. On the other hand, structural differences were also found in the inferior parietal sulcus, which is known that it has a big role in recalling vivid episodic memories. Also, increased white matter volumes that provide information transfer within the brain regions were found in HSAM individuals. It was emphasized that increased regional grey matter volumes especially in the anterior putamen, caudate and posterior pallidum may explain the possibility of obsessive tendencies and memory habits in HSAM cases.

It was emphasized that HSAM cases may have obsessive tendencies. As a result of the neuropsychological tests performed in the case of $\mathrm{AJ}$, it was concluded that there could be deficiencies in the areas of dorsolateral prefrontal cortex, lateral orbifrontal cortex, cingulate, supplementary motor areas and associated basal ganglia structures that responsible for disorders such as autism, obsessive-compulsive disorder, ADHD and therefore, these results were interpreted that $\mathrm{AJ}$ case may have obsessive compulsive tendencies ${ }^{5}$. On the other hand, although hesitating to establish a direct connection between them, LePort et al. suggested that HSAM and OCD could be have common underlying mechanism because the results showed that structural changes in the areas of anterior putamen, caudate and posterior pallidum in OCD patients were also observed in HSAM participants and that HSAM individuals scored higher than controls in Leyton Obsessional Inventory Short Form ${ }^{2}$. LePort et al. stood on the possibility that HSAM individuals could be incidentally strengthened their autobiographical memory because of their obsessive habits, by showing some obsessive characteristics as an evidence such as routine ruminations or perseverations in HSAM cases ${ }^{7}$. Although similarities were found in an orbito-striatal areas between HSAM and OCD and the Functional Mode Network contributed to HSAM, but it was concluded that HSAM is different from OCD. In this context, future studies are needed to reveal the relationship between HSAM and OCD.

\section{CONCLUSION}

There are many controversial points and questions about the extraordinary memory of HSAM participants. For example, some questions such as 
how HSAM has a relationship with OCD, what else neurobiological and behavioral differences are available between HSAM and OCD, how the development process of autobiographical memory in HSAM individuals takes place and what are the advantages or disadvantages of having HSAM are the questions to be answered. Future studies on these issues, especially studies with HSAM cases in different developmental stages will clarify the questions in our minds. As a result, our rich knowledge of HSAM will provide unique information about the functioning of autobiographical memory.

\section{REFERENCES}

1. LePort AKR, Stark SM, McGaugh JL, Stark CEL. A cognitive assessment of highly superior autobiographical memory. Memory 2017; 25(2): 276- 288.

2. LePort AKR, Mattfeld AT, Dickinson-Anson $\mathrm{H}$, Fallon JH, Stark CE, Kruggel F, et al. Behavioral and neuroanatomical investigation of highly superior autobiographicalmemory (HSAM). Neurobiol Learn Mem 2012; 98: 78-92.

3. Patihis L.Individual differences and correlates of highly superior autobiographical memory. Memory 2016; 24: 961-978.

4. Patihis L, Frenda SJ, LePort AK, Petersen N, Nichols RM, Stark CE, et al. False memories in highly superior autobiographical memory individuals. Proc Natl Acad Sci USA 2013; 110: 20947-20952.

5. Parker ES, Cahill L, McGaugh JL. A case of unusual autobiographical remembering. Neurocase 2006; 12: 35-49.

6. Henkle, W. D. (1871). Remarkable cases of memory. The Journal of Speculative Philosophy, 5, 6-26.

7. LePort AKR, Stark SM, McGaugh JL, Stark, CEL. Highly superior autobiographical memory: Quality and quantity of retention over time. Front Psychol 2016; 6: 2017.

8. Svoboda E, McKinnon MC, Levine B. The functional neuroanatomy of autobiographical memory: A meta-analysis. Neuropsychologia 2006; 44: 2189-2208.

9. Levine B, Turner GR, Tisserand D, Hevenor SJ, Graham SJ, McIntosh AR. The functional neuroanatomy of episodic and semantic autobiographical remembering: A prospective functional MRI study. J Cognitive Neurosci 2004;16(9): 1633-1646.

10. Steinvorth S, Corkin S, Halgren E. Ecphory of autobiographical memories: An fMRI study of recent and remote memory retrieval. NeuroImage 2006; 30: 285-298.

11. Piefke M, Weiss PH, Markowitsch HJ, Fink GR, 2005. Gender differences in the functional neuroanatomy of emotional episodic autobiographical memory. Hum Brain Mapp 2005; 24: 313-324.

12. Cabeza R, St. Jacques PL. Functional neuroimaging of autobiographical memory. Trends Cogn Sci 2007; 11: 219-227. 